\title{
DÜBLIN
}

Technological University Dublin

ARROW@TU Dublin

\section{Identification of Volatile Quality Markers of Ready-to-use Lettuce and Cabbage}

\author{
Catherine Barry-Ryan \\ Technological University Dublin, Catherine.Barryryan@tudublin.ie \\ Michael Devereux \\ Technological University Dublin, Michael.Devereux@tudublin.ie \\ Julien Lonchamp \\ Technological University Dublin, jacklonch@hotmail.com
}

Follow this and additional works at: https://arrow.tudublin.ie/schfsehart

Part of the Food Science Commons

\section{Recommended Citation}

Barry-Ryan, C.,Devereux, M. \& Lonchamp, J. (2009) Identification of volatile quality markers of ready-touse lettuce and cabbage. Food Research International, 42 (2009),pp. 1077-1086 doi :10.1016/ j.foodres.2009.05.002

This Article is brought to you for free and open access by the School of Food Science and Environmental Health at ARROW@TU Dublin. It has been accepted for inclusion in Articles by an authorized administrator of ARROW@TU Dublin. For more information, please contact arrow.admin@tudublin.ie, aisling.coyne@tudublin.ie, gerard.connolly@tudublin.ie.

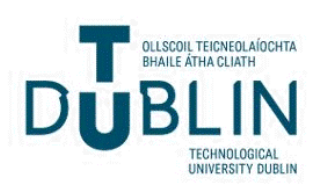




\title{
Identification of volatile quality markers of ready-to-use lettuce and cabbage Food Research International 42 (2009) 1077-1086
}

\author{
Julien Lonchamp $a,{ }^{*}$, Catherine Barry-Ryan a, Michael Devereux b
}

\author{
a. School of Food Science and Environmental Health, Dublin Institute of Technology, \\ Cathal Brugha Street, Dublin 1, Ireland \\ b. College of Sciences and health, Dublin Institute of Technology, Kevin Street, Dublin \\ 8, Ireland
}

Keywords: Volatile compounds, Detection, Marker, Sensory quality, Monitoring, Ready-to-use vegetables

\begin{abstract}
Volatile emission changes of ready-to-use vegetables directly result from minimal processing and can reflect the sensory changes occurring in the product. Based on the detection of key volatile compounds, novel on-line and consumer quality-monitoring methods can be developed. The aim of this study was to identify volatile biomarkers for a range of leafy green ready-to-use vegetables (Butterhead and Iceberg lettuce and Irish York cabbage). Headspace volatile compounds were monitored using gas chromatography/mass spectrometry (GC/MS). The sensory quality of the products was evaluated at days 1,7 and 14 using sensory and analytical measurements. Changes of volatile concentrations and sensory attributes were statistically correlated. The main quality markers identified for active modified atmosphere packaged (MAP) Butterhead lettuce were: 2-ethyl-1-hexanol, cis-3-dodecene, 4-ethylbenzaldehyde, acetocinnamone, b-elemene, 1-chlorododecane, dimethylethylphenol, ester pentanoic acid and thio-aminobutanamide. The main indicators of freshness were dimethylethylphenol and ester pentanoic acid, while the main quality loss markers were cis-3-dodecene and b-elemene.
\end{abstract}

\section{Introduction}

Over the past two decades, consumers have been seeking more and more convenient food products as either semi-prepared or fully prepared meal items such as minimally processed and modified atmosphere packaged (MAP) vegetables. Manufacturers of these ready-to-use products are now more concerned with sensory quality improvement and extension. The problem associated with ready-to-use vegetables is their short shelf-life: $5-7$ days for Iceberg lettuce stored in adequate conditions (chill-chain and below $4^{\circ} \mathrm{C}$ ) (Carlin, Nguyen-The, Hilbert, \& Chambroy, 1990). This rapid loss of quality is due to the influence of minimal processing unit operations, such as cutting and disinfecting, on the "natural" causes of degradation (respiration, senescence and inherent microbial flora). Beyond day 7 of storage, these products suffer from loss of freshness (losses of aroma, green color and crispness) and development of quality loss factors (browning, off-flavors and microbial deterioration) (Lopez-Galvez, Peiser, Nie, \& Cantwell, 1997; Zhou et al., 2004), making them more perishable than unprocessed material (Watada \& Qui, 1999).

Improving the organoleptic profile of these products requires a better understanding of their sensory changes and the development of novel quality-monitoring tools. The metabolic pathways influencing the sensory quality of the products produce various compounds, among which some are volatile. While some of these volatile compounds are naturally released by horticultural products, most of them are present in unprocessed produce in non-volatile precursor forms, such as terpene glycosides (Lalel, Singh, \& Tan, 2003) and glucosides of phenolic compounds (Sarry \& Gunata, 2004). These compounds are only released as a consequence of cutting during minimal processing (Sarry \& Gunata, 2004). Other volatile emissions can result from stress-induced metabolic pathways triggered by minimal processing.

Volatile compounds are therefore potential biomarkers of quality changes occurring as a result of minimal processing. Based on the detection of key volatile compounds, novel quality-monitoring methods can be developed. These methods would be rapid and non-destructive of the product, allowing their use at an industrial level as a rapid on-line unit monitoring the volatile profile, and at the consumer level with the development of active food labels that would respond to biomarker changes. As certain compounds are emitted as signals of metabolic changes, these on-line units or food labels could indicate the early detection of quality loss changes on a production line or to the consumer. These quality-monitoring methods could also be applied to test and optimise the processing and packaging of ready-to-use vegetables in shelf-life trials, with a view to extending their shelf-life.

Volatile emissions reported for lettuce include cis-3-hexenal, cis-3-hexenol, cis-3-hexenylacetate, short-chain methylated alcohols and esters, sulfides, terpenes and furans (Charron, Cantliffe, Wheeler, Manukian, \& Heath, 1996a, 1996b; Smyth, Song, \& Cameron, 1998). Cabbage volatiles identified include sulphur compounds, mainly disulphides, isothiocyanates, ketones, short-chain 
alcohols and aldehydes and monoterpenes (Johnson, Nursten, \& Williams, 1971; Vuorinen, Reddy, Nerg, \& Holopainen, 2004). Only a few studies have reported possible biomarkers within the volatile emission profile of leafy green vegetables. Several compounds have been reported as contributing to leafy green vegetable aromas. Cis-3-hexen-1-ol and trans-2-hexenal have been associated with leaf aroma in lettuce (Arey et al., 1991). Pyrazines and terpenes are known to contribute to the green flavor of many vegetables (Fischer \& Scott, 1997), with 3-alkyl-2-methoxypyrazine (isopropyl, sec-butyl and isobutyl forms) contributing to the aroma of the heart and paler fleshy parts of the lettuce (Charron \& Cantliffe, 1995) and to cabbage aroma (Belitz \& Grosch, 1987)

On the other hand, Smyth et al. (1998) showed that the presence of dimethyl sulfide in 10 day-old ready-to-use lettuce was responsible for the development of a putrid aroma (Smyth et al., 1998). Some volatile emission changes were shown to occur as a result of mechanical injury. An increase of cis-3-hexen-1-ol and cis-3-hexenylacetate was observed in bruised-head lettuce by Charron and Cantliffe (1995). Finally, potential stress biomarkers were suggested. In lettuce, the concentrations of acetaldehyde and ethanol, two products of anaerobic metabolism, increased in stressful conditions (such as wounding induced by cutting) (Charron \& Cantliffe, 1995; Lopez-Galvez et al., 1997). Chin and Lindsay (1993) reported a production of methanethiol by disrupted tissues of cabbage.

To date, no comprehensive study has assessed correlations between volatile compound emissions and sensory properties changes of minimally processed vegetables. The aims of this study are to address this gap of knowledge and identify possible quality markers among the volatile compounds emitted by a range of leafy green ready-to-use vegetables (Butterhead and Iceberg lettuce and Irish York cabbage) bags were cut and sealed using an impulse heat sealer (SMS 350, Packer Products, Basildon, UK).

\subsection{Modified atmosphere packaging}

Higher quality products were active modified atmosphere packaged (MAP) using a Multi Vac packaging machine (Webomatic C1011, Werner Bonk, Bochum, Germany). The composition of the initial MAs were: $0.3 \% \mathrm{O}_{2}$ and $8.4 \% \mathrm{CO}_{2}$ for Butterhead lettuce, $0.2 \% \mathrm{O}_{2}$ and $7.5 \% \mathrm{CO}_{2}$ for Iceberg lettuce and $1.2 \% \mathrm{O}_{2}$ and $5.8 \%$ $\mathrm{CO}_{2}$ for Irish York cabbage. Nitrogen was the balance gas. A preliminary study showed that these optimised initial levels provided suitable equilibrium modified atmospheres (EMA) during the first week of storage (results not shown). Poorer quality products were passive MA-packaged, with bags heat-sealed with no flushing using an impulse heat sealer (SMS 350, Packer Products, Basildon, UK).

\subsection{Experimental design}

The overall quality of the products was evaluated at days 1, 7, 11 and 14 . Headspace $\mathrm{O}_{2}$ and $\mathrm{CO}_{2}$ composition, sensory analysis, and instrumental color and texture measurements were monitored. Three bags were analysed per treatment at each analysis day. Headspace composition, color, texture and sensory measurements were carried out on the same bags. Headspace volatiles were monitored on a daily basis using gas chromatography-mass spectrometry (GC-MS). Gas chromatography-olfactometry (GC-O) was carried out on days 1, 7, 11 and 14. Two samples for each of the two treatments (active and passive MAP) were chosen for the MS and GC-O analyses. Each experiment was carried out twice. Statistical analysis was performed using the SPSS 9.0 (SPSS Inc., Chicago, USA).

\subsection{Sensory analysis}

Sensory attributes were monitored by a trained panel of 10 people (four females and six males aged 24-39 years old) using the Compusense five software (Compusense Inc., Guelph, Canada). The panel was asked to evaluate the characteristic aromas (green, fresh and lettuce/cabbage odors) and the possible off-odors (musty, rotten and overall off-odors) of products. The intensity of green color was examined, as well as possible off-colors: leaf surface browning (LSB), leaf edge browning (LEB) and yellowing. Texture (firmness \{finger-feel\} and crispiness \{force required to break the leaf\}) and overall sensory quality were finally evaluated.

\subsection{Quality marker measurements}

The $\mathrm{CO}_{2}$ and $\mathrm{O}_{2}$ concentrations of the headspace atmosphere were determined using a portable gas analyser (MAP Test, AGB Scientific Ltd., Dublin, Ireland). Color measurement was performed using a Color Quest XE colorimeter (Hunter Lab, Northants, UK). Nine random areas were measured through the packaging film. $L^{*}, a^{*}$ and $b *$ color readings were recorded: $L *$ (lightness, from 0 for black to 100 for white), +a*(redness), Àa*(greenness), $+b *$ (yellowness), Àb*(blueness). Three other color terms were calculated from the values of $L^{*}, a *$ and $b *$ chroma difference with the green initial standard (DC*), hue angle difference with the green initial standard $\left(\mathrm{DH}^{*}\right)$ and total color difference with the green initial standard (DE*). Texture measurements were carried out using an Instron Universal Testing machine (model 4464, Instron Limited, High Wycombe, UK) mounted with a $500 \mathrm{~N}$ load cell. The maximal force applied at the breaking point of the leaf was recorded in Newtons. One reading per leaf was taken. For each treatment, all the pieces of one package were analysed (approximately 
60 leaves per treatment). The sensory and analytical measurements of quality attributes were statistically correlated.

\subsection{Volatile emission analysis}

Headspace volatile compounds were collected using a solid phase micro-extraction (SPME) device (Supelco, JVA Analytical Ltd., Ireland). The fiber coating used was a $100-1 \mathrm{~m}$ polydimethylsiloxane (PDMS) film. Before each volatile compound extraction, the SPME fiber was conditioned in the GC-MS injector port set at $250{ }^{\circ} \mathrm{C}$ for $5 \mathrm{~min}$. The fiber was then inserted through the plastic film, exposed for $5 \mathrm{~min}$ and retracted. The SPME device was finally inserted into the GC-MS injection port and exposed for $3 \mathrm{~min}$. A CP-Sil 8 fused-silica capillary column (length $=30 \mathrm{~m}$, inner diameter $=0.25 \mathrm{~mm}$, film thickness $=0.25 \mathrm{~lm}$ ) (JVA Analytical Ltd., Dublin, Ireland) was used. Injections were conducted splitless. The oven temperature was first maintained at $30^{\circ} \mathrm{C}$ for $5 \mathrm{~min}$. The temperature was then increased to $250^{\circ} \mathrm{C}$ at a rate of $5{ }^{\circ} \mathrm{C} / \mathrm{min}$. The final temperature of $250^{\circ} \mathrm{C}$ was maintained for $15 \mathrm{~min}$. A manual switching valve (JVA Analytical Ltd., Dublin, Ireland) either orientated the flow to the MS or divided the flow between the flame ionization detector (FID) of the GC and the sniffer-port after column elution. MS analysis was carried out using a Varian 2200 MS (JVA Analytical Ltd., Dublin, Ireland). GC-O analysis was carried out using a Varian CP3800 GC (JVA Analytical Ltd., Dublin, Ireland).

Data were collected using the Varian software and mass spectra of detected compounds were analyzed by library searching in the National Institute of Standards and Technology (NIST) databases. Estimation of the volatile compounds quantity was based on the areas of the peaks detected by MS. The headspace concentration of a volatile compound was then expressed in percentage of total volatile compounds detected or percentage of the total peak area. Five standard chemicals were injected to validate the method: 2-ethyl-1-hexanol,1-chlorododecane,trans-cinnamaldehyde, isomethyl b-ionone and p-xylene (Aldrich Chemical Co., Dublin, Ireland). Their mass spectra and retention times matched with those of the corresponding quality-related volatile compounds detected. The compounds were identified with high probabilities when compared with standards from the NIST database (similarity coefficient Sim or reverse similarity coefficient RSim >85\%). Additional information about the compounds detected was provided by Flavornet, an online compilation of aroma compounds found in human odor space.

\section{Results and discussion}

\subsection{Headspace $\mathrm{O}_{2}$ and $\mathrm{CO}_{2}$ measurements}

For all active MA-packaged samples the $\mathrm{O}_{2}$ increased and $\mathrm{CO}_{2}$ decreased over the 14 days of storage. A suitable EMA of $2-5 \% \mathrm{O}_{2}$ and $5-8 \% \mathrm{CO}_{2}$, as defined by Lopez-Galvez et al. (1997) and Hamza, Castaigne, Willemot, Doyon, and Makhouf (1996), was reached at day $3 / 4$ and lasted until day $7 / 8$ for these three higher quality products. Mc Kellar et al. (2004) observed a similar evolution of $\mathrm{CO}_{2}$ in active MA-packaged bags of polyethylene-polypropylene (PE-PP) copolymer, containing $340 \mathrm{~g}$ of Iceberg lettuce packaged in $5 \% \mathrm{CO}_{2}$. For passive MA-packaged lettuce, the headspace composition did not significantly change over storage. Similar evolutions were previously observed in passive MA-packaged PP bags of crisphead lettuce (Rosenfeld \& Sundell, 1992) and whole Iceberg lettuce heads (Martinez \& Artes, 1999). For passive MA-packaged cabbage, an EMA was maintained between days 2 and 4 , but the $\mathrm{O}_{2}$ concentration was unsuitable during the whole storage $(>5 \%)$. All three passive MA-packaged products were stored in unsuitable atmo- spheres over storage and were used as low quality standards for sensory analysis.

\subsection{Sensory analysis}

Between days 1 and 14, most of the freshness attributes significantly decreased while most of the quality loss factors increased for all three vegetables $(p<0.05)$ (Fig. 1). Between days 1 and 7 , the freshness parameters all decreased for Butterhead lettuce and Irish York cabbage, while all the quality loss factors increased for Irish York cabbage. In passive MA-packaged Iceberg lettuce, aromas and texture decreased while off-odors increased (Fig. 1d), but not with active MAP (Fig. 1c). Off-odors were also minimised in shredded packaged lettuce stored similarly in an EMA of 1-3\% $\mathrm{O}_{2}$ and 5-6\% $\mathrm{CO}_{2}$ (Ballantyne, Stark, \& Selman, 1998). For Iceberg lettuce, losses of green color and quality were significant, while browning increased. Zhou et al. (2004) and Bianco (1990) similarly reported color changes as the main factor limiting the shelf-life of packaged lettuce. Between days 7 and 14, all the freshness parameters decreased and all the quality loss factors increased for Butterhead lettuce. On the contrary, organoleptic changes were limited for Iceberg lettuce and cabbage.

At day 1 , no statistical differences were observed between ac tive and passive MAP for all three vegetables. By day 7 , active MA-packaged Butterhead lettuce presented higher lettuce aroma and firmness and weaker off-odors and browning than with passive MAP $(p<0.05)$ (Fig. 1a and b). Preservation of texture and aroma and control of browning by active MA were previously reported for Lollo Rosso lettuce in comparison with passive MA (Gil, Castaner, Ferreres, Artes, \& Tomas-Barberan, 1998). At day 7 active MA-packaged Iceberg lettuce presented lower yellowing and higher visual and overall quality. Similarly, between days 1 and 7 , aromas decreased and off-odors and yellowing increased more significantly in passive MA-packaged cabbage. At day 14 , off-odors were higher in passive MA-packaged Butterhead lettuce and cabbage. For Iceberg lettuce, higher lettuce aroma and visua quality and lower off-odors were reported with active MAP.

By day 7, active MA-packaged lettuce had higher visual and overall sensory scores than with passive MAP $(p<0.05)$. For all three vegetables, active MA-packaged samples were considered acceptable until day 11, whereas passive MA-packaged standards were inconsumable from day 7 . Visual quality was also better preserved in active MA for Lollo Rosso lettuce (Gil et al., 1998). Li, Brackett, Shewfelt, and Beuchat (1991) similarly reported a limit of saleability (last day of storage at which the panel judged that the product could still be sold) below 7 days for passive MA-packaged Iceberg lettuce treated in warm chlorinated water. The shelflife obtained in this study (11 days) was shorter than the 14 days reported for whole Iceberg lettuce heads in active and passive MA-packaged PP bags using the same scaling system (Martinez \& Artes, 1999). This difference confirmed the effects of the stress caused by cellular disruption during minimal processing on quality (Hamza et al., 1996; Yao \& Tian, 2005; Choi, Tomas-Barberan, \& Salveit, 2005).

The appearance and development of off-odors were the main parameters influencing the judgment of the panellists. The higher quality Iceberg lettuce and Irish York cabbage samples better retained the aroma profile during the first 7 days, and the development of off-odors was limited in these products during the following 7 days. Similarly, Ballantyne et al. (1998) reported no off-odors in active MA-packaged shredded Iceberg lettuce. Between day 7 and day 14, active MAP delayed the appearance and development of quality loss factors. The sensory analysis results confirmed the active MA-packaged products as high quality products in comparison with poorer-quality passive MA-packaged standards. 

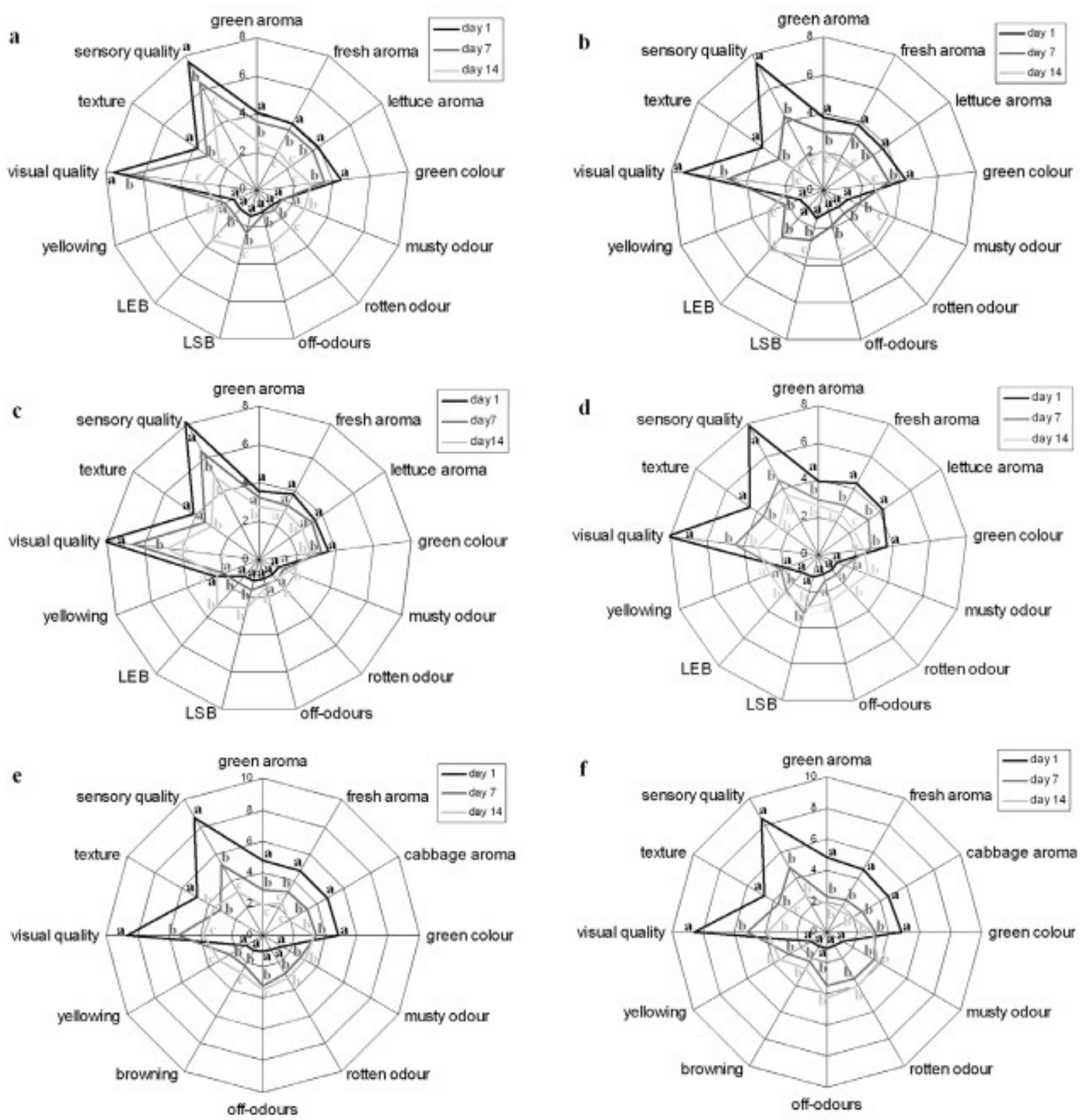

Fig. 1. Evolution of the sensory profile of active versus passive MA-packaged Butterhead lettuce (respectively, a and b), Iceberg lettuce (c and d) and Irish York cabbage (e and f) over storage (Lonchamp, Barry-Ryan and Devereux). LSB: leaf surface browning, LEB: leaf edge browning. Different letters signify statistical differences between values $(\mathrm{p}<0.05)$ for each attribute.

\subsection{Analytical color and texture measurements}

For Butterhead lettuce, $\mathrm{a}^{\star}$ and $\mathrm{DH} *$ proved statistically $(\mathrm{p}<0.05)$ sensitive over storage time, on the contrary of $L^{*}, b^{*}, D E *$ and $D C *(r e-$ sults not shown). From days 1 to 7 , a* increased and remained negative, which meant a loss of green color. For passive MAP, products were less green at day 14 than at day 1 , confirming the sensory results. Browning can be expressed by the $a^{\star}$ value, which varies from green $\left(a^{*}<0\right)$ to red $\left(a^{*}>0\right)$, as suggested by Hamza et al. (1996) Based on the $a^{\star}$ reading, browning developed between days 1 and 7 and over storage for passive MAP, confirming the sensory results. $\mathrm{DH} \star$ decreased at all stages of storage, possibly due to the loss of the pigment chlorophyll via chlorophyllase activity, as suggested by Bolin and Huxsoll (1991) for green color changes. For Iceberg lettuce and Irish York cabbage, none of the Color Quest parameters statistically changed over time, as previously reported by Smyth et al. (1998) for passive MA-packaged Iceberg lettuce. The nonhomogeneous green color and susceptibility to browning of these vegetables could explain this absence of detectable color changes.

The firmness of Butterhead lettuce measured using the Instron did not decrease from days 1 to 7 and from days 7 to 14 , as opposed to sensory results. A loss of firmness $(p<0.05)$ was reported over storage for active MAP, but not for passive MAP as opposed to sensory results. Both sensory and analytical measurements indicated a loss of firmness over storage for Iceberg lettuce and Irish York cabbage. No textural differences were found between the higher and lower quality products for all three vegetables, due to the vast heterogeneity of texture between leaves and within a leaf previously observed by Toole, Parker, Smith, and Waldron (2000) for Butterhead lettuce.

For active MA-packaged Iceberg lettuce and Irish York cabbage, color and quality parameters showed a correlation with 
Table 1

Volatile emission patterns of MA-packaged Butterhead lettuce, Iceberg lettuce and Irish York cabbage over storage.

\begin{tabular}{|c|c|c|c|c|c|c|c|c|c|}
\hline \multirow[t]{2}{*}{$\begin{array}{l}\text { Time } \\
(\mathrm{min})\end{array}$} & \multirow[t]{2}{*}{ Major $\mathrm{m} / \mathrm{z}$ ions } & \multirow[t]{2}{*}{ Volatile compound } & \multirow[t]{2}{*}{ Aromas/odors } & \multicolumn{2}{|c|}{$\begin{array}{l}\text { Butterhead } \\
\text { lettuce }\end{array}$} & \multicolumn{2}{|c|}{$\begin{array}{l}\text { Iceberg } \\
\text { lettuce }\end{array}$} & \multicolumn{2}{|c|}{$\begin{array}{l}\text { Irish York } \\
\text { cabbage }\end{array}$} \\
\hline & & & & aMA & pMA & aMA & pMA & aMA & $\mathrm{pMA}$ \\
\hline Volatile & pounds of vegetable origin & & & & & & & & \\
\hline 9.355 & 3,111 & 1,1,3-Trimethylcyclohexane & Green, sweet & & & & & u & \\
\hline 10.351 & $77,91,106$ & Ethyl benzene & Green, cabbage & & & & & u & \\
\hline 10.651 & $77,91,106$ & P-xylene & $\begin{array}{l}\text { Fresh, citrus } \\
\text { (plastic) } \\
\text { Fresh (plastic) }\end{array}$ & & & & & u & u \\
\hline 10.7 & $51,65,77,91,106$ & M-xylene & Green (geranium) & & & & & & \\
\hline 11.5 & $51,65,77,91,106$ & $\begin{array}{l}\text { - g-xylene } \\
\text { O-xylent }\end{array}$ & Musty, cabbage & & & & & u & U \\
\hline 11.9 & $57,70,85$ & 2,5,6-Trimethyldecane & Citrus (lemon) & & & & & u & u \\
\hline 13.1 & $77,79,91,93$ & $\begin{array}{l}\text { 2,5,6-Irrmetnyldecane } \\
\text { 3-Carene }\end{array}$ & Cabbage, fresh & & & & & $U$ & $U$ \\
\hline 13.8 & $193,209,211$ & 2-Formyl-4,6-dimethoxy-8,8-dimethoxyoct-2-yl ester & & & & & & $U$ & u \\
\hline & & $\begin{array}{l}\text { 2,2,3-Trimethylbicyclo-(2.2.1)-heptane } \\
\text { Cis-4-hexen-1-ol }\end{array}$ & & & & & & u & u \\
\hline 14.7 & 193,211 & $1,3,5$-Trimethylbenzene & & $\mathrm{u}$ & & & & & \\
\hline 15.8 & 67,82 & Cymene & Fresh (green) & & & & & $\mathrm{u}$ & \\
\hline 16.3 & $71,105,120$ & & Musty & & & & & u & \\
\hline 16.4 & $57,91,119,134$ & & Green (solvent, & $\mathrm{U}$ & $\mathrm{U}$ & & & $u$ & $U$ \\
\hline 16.5 & $53,67,79,93,107,121,136$ & Limonene & $\begin{array}{l}\text { Green (lemon, } \\
\text { orange) } \\
\text { Musty (rose, } \\
\text { green*) }\end{array}$ & $\mathrm{U}$ & $u$ & & & $U$ & \\
\hline 16.6 & $41,55-57,70,83$ & 2-Ethyl-1-hexanol & & $u$ & $U$ & $U$ & $U$ & $U$ & $u$ \\
\hline 18.2 & $43,55,85,127$ & 2-Ethyl-1,6-dioxaspiro-4,4- nonane & & $\mathrm{U}$ & & & & & \\
\hline 18.5 & $91,115-117,132$ & 2-Methyl-1-propenyl-benzene & & $\mathrm{u}$ & & & & & \\
\hline 18.6 & $41,55,69,83,97$ & Cis-3-dodecene & & u & & & & & \\
\hline 19.0 & $41,57,67,81,95$ & Nonanal & Rotten, musty & u & $\mathrm{u}$ & $\mathrm{u}$ & & $\mathrm{u}$ & \\
\hline 19.4 & $50,77,115,130$ & 1-Methylene-2-propenylbenzene & (soapy) & & & & & & \\
\hline 20.3 & 293 & $\mathrm{~N}$-Methylyohimbane & & & & & & & \\
\hline 20.9 & $50,105,133$ & 4-Ethylbenzaldehyde & & & & & & u & \\
\hline & & & $\begin{array}{l}\text { Musty } \\
\text { Fresh cabbage }\end{array}$ & u & $u$ & u & 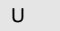 & & \\
\hline & & & (sweet) & $\mathrm{U}$ & U & & & $\mathrm{U}$ & $U$ \\
\hline 21.4 & $91,105,133-134$ & 3,5-Dimethylbenzaldehyde & & $\mathrm{u}$ & & & & & \\
\hline 22.2 & $61,103,131,177$ & Trans-cinnamaldehyde & $\begin{array}{l}\text { Fresh, pine } \\
\text { (cinnamon) }\end{array}$ & u & & & & $U$ & $u$ \\
\hline 21.6 & $41,55,69,83,97$ & Decene & & $\mathrm{u}$ & & & & & \\
\hline 22.1 & $41,57,67,85$ & Dodecanal & & u & & & & & \\
\hline 22.7 & $66,77,94,138$ & 2-Phenoxyethanol & & $u$ & & & & & \\
\hline 24.5 & $59,103,131,146$ & Acetocinnamone & Musty, rotten & u & u & & u & u & u \\
\hline 25.0 & $59,91,119,134$ & 2-Methylcoumaran & Green & $\mathrm{u}$ & & & & $\mathrm{u}$ & \\
\hline 25.3 & $50,76,104$ & Bicyclo(4.2.0)-octa-1,3,5-triene-7,8-dione & Fresh & U & & & & $\mathrm{U}$ & \\
\hline 26.1 & $71,118,146,174$ & 1,3-Diisocyanato-2-methylbenzene & & & $U$ & & & & u \\
\hline 26.2 & $91,105,119,132$ & a-Longipinene & & & U & & & & \\
\hline 26.3 & $50,91,145,174$ & 2,4-Diisocyanato-1-methylbenzene & Musty & $u$ & U & $\mathrm{U}$ & $\mathrm{U}$ & & \\
\hline 26.7 & $91,105,119,133,148,161$ & (+)-Cylcosativene & Rotten & $u$ & U & u & $u$ & & \\
\hline 26.9 & $73,91,105,119,161,204$ & Copaene & Musty & $u$ & U & $\mathrm{u}$ & $\mathrm{u}$ & & \\
\hline & & & Green & u & 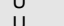 & & U & $\mathrm{u}$ & u \\
\hline & & & $\begin{array}{l}\text { Green (wood, } \\
\text { spice) }\end{array}$ & u & & & u & & \\
\hline 27.2 & $77,94,104,121 / 122$ & 2-Methyl-1,3-benzenediamine & & & $\mathrm{U}$ & & & & \\
\hline 27.2 & $67,79,93,107,119,133,161$ & b-Elemene & Musty & $\mathrm{U}$ & U & $\mathrm{U}$ & $\mathrm{U}$ & & \\
\hline 27.5 & $57,71,93,106,120,148$ & 2,3-Dihydroamino-indole-2-one & Vegetable & u & U & $\mathrm{u}$ & u & & \\
\hline 27.8 & $106,120,148$ & 3-Methyl-2H-benzimidazol-2-one & vegetanie & $\mathrm{U}$ & $u$ & U & U & $\mathrm{u}$ & \\
\hline 28.0 & 107, 135, 191 & Isomethyl b-ionone & & & & & & & \\
\hline 27.8 & $106,120,148$ & 3-Methyl-2H-benzimidazol-2-one & & & & & & & \\
\hline 28.0 & $107,135,191$ & Isomethyl b-ionone & & u & & & & & \\
\hline 28.1 & $67,79,91,103,119,133,161$ & Caryophyllene & & & $u$ & & & & \\
\hline & & & & $\mathrm{u}$ & & & & & \\
\hline & & & $\begin{array}{l}\text { Green (wood, } \\
\text { spice) }\end{array}$ & u & $U$ & $U$ & $U$ & & \\
\hline 28.6 & $69,93,107,121,136,151$ & 6,10-Dimethyl-5,9-undecadien-2-one & & 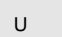 & $u$ & $\mathrm{u}$ & $\mathrm{u}$ & & \\
\hline 30.1 & $77,91,105,133,161,189,204$ & Valencene & & u & u & $\mathrm{u}$ & & & \\
\hline 30.0 & $145,177,205,220$ & Butylated hydroxytoluene & & $u$ & $u$ & $u$ & & & \\
\hline 30.1 & & 2,6-Bis-dimethylethyl-1,4-benzenediol & Fresh (paint) & u & u & U & $\mathrm{u}$ & & \\
\hline 30.1 & & 2,6-Ditertbutyl-benzoquinone & $\begin{array}{l}\text { (sweet, flower) } \\
\text { Musty }\end{array}$ & & & & $u$ & & \\
\hline & $\begin{array}{l}91,107,119,135,149,163,177, \\
207,220\end{array}$ & & & & & & & $u$ & $u$ \\
\hline & 191,206 & & & & & & & & \\
\hline 30.2 & $41-43,71$ & 2,4-Bis (1,1-dimethylethyl)-phenol & Green (phenol) & $\mathrm{u}$ & $\mathrm{u}$ & $\mathrm{u}$ & $\mathrm{u}$ & $\mathrm{u}$ & $\mathrm{u}$ \\
\hline 32.1 & & 2,2,4-Trimethyl-3-carboxyisopropyl isobutyl ester & Green, fresh & U & 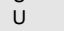 & 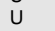 & $\mathrm{U}$ & $\mathrm{U}$ & 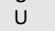 \\
\hline & & $\begin{array}{l}\text { pentanoic acid } \\
\text { Caryophyllene oxide }\end{array}$ & & & & & & & \\
\hline 32.2 & 770,850 & Diethylphtalate & & 11 & & & & & \\
\hline 32.2 & 149,177 & Diphenyl sulfide & Musty & U & & & & & \\
\hline 32.3 & $51,185-186$ & N-Methyl-4-(methylthio-2-(2,2-dimethylpropylidene)- & Musty & & & & & u & $\mathrm{u}$ \\
\hline 33.4 & $55,83,99,111,155,173$ & amino-butanamide & & $\mathrm{u}$ & $\mathrm{u}$ & $\mathrm{u}$ & $\mathrm{u}$ & $U$ & \\
\hline & & Methyl dihydrojasmonate & Musty & $U$ & $U$ & $\mathrm{U}$ & $U$ & U & \\
\hline & & 3,4-Diethyl-1,1-biphenol & & & & & & & \\
\hline 33.6 & $83,153,156$ & 3,5-Di-tert-butyl-4-hydroxybenzaldehyde & (jasmine) & $\mathrm{u}$ & $\mathrm{u}$ & & U & & \\
\hline 35.8 & $166,181,210,221$ & & & $\mathrm{U}$ & U & & U & & \\
\hline 35.9 & 234 & & & U & $u$ & & $U$ & & \\
\hline & & & sugar) & & & U & & & \\
\hline 36.4 & $87 \quad 115 \quad 143 \quad 162$ & Pentanedinic acid diethyl ester & Musty & & & & & & \\
\hline $\begin{array}{l}36.4 \\
37.2\end{array}$ & $87,115,143,162$ & Pentanediolc acld diethyl ester & & $\mathrm{u}$ & & & & & \\
\hline 37.2 & 196 & Bis-1-methylethyl-1,1-biphenol & & $u$ & $u$ & & $\begin{array}{l}U \\
\text { tinued }\end{array}$ & next $p$ & \\
\hline
\end{tabular}


Table 1 (continued)

\begin{tabular}{|c|c|c|c|c|c|c|c|c|}
\hline \multirow[t]{2}{*}{ Time (min) } & \multirow[t]{2}{*}{ Volatile compound } & \multirow[t]{2}{*}{ Aromas/odors } & \multicolumn{2}{|c|}{$\begin{array}{l}\text { Butterhead } \\
\text { lettuce }\end{array}$} & \multicolumn{2}{|c|}{$\begin{array}{l}\text { Iceberg } \\
\text { lettuce }\end{array}$} & \multicolumn{2}{|c|}{$\begin{array}{l}\text { Irish York } \\
\text { cabbage }\end{array}$} \\
\hline & & & aMA & pMA & $\mathrm{aMA}$ & pMA & aMA & pMA \\
\hline \multirow{2}{*}{\multicolumn{2}{|c|}{$\begin{array}{l}\text { 37.255, 70, 99, 127, 155, } 173 \text { 6-Butoxy-3,6-dihydro-2H-pyran-2-carboxylic acid ethyl ester } \\
\text { 37.341, 55, 99, 127, 154-155 3-Methylglutakonic acid diethyl ester } \\
\text { 38.0149, 223Diisobutylphtalate } \\
\text { 38.9149Dibutylphtalate } \\
\text { 39.0196Diisopropylbiphenol } \\
\text { 40.12437-Acetyl-6-ethyl-1,1,4,4-tetramethyltetralin } \\
\text { 40.1243/2444-(4-Butylcyclohexyl)-2,3-dicyanophenylester benzoic acid } \\
\text { 41.640, 71, 119, 213, 2282-(1-(4-Hydroxyphenyl)-1-methylethyl)-Phenol } \\
\text { 44.151, 119, 213, 2284,4-(1-Methylethylidene)-bis-phenol } \\
\text { 46.9239, 299Phenanthrene carboxylic acid } \\
\text { 49.971, 149, 167, 279Mono-(2-ethylhexyl) ester 1,2-benzene dicarboxylic acid } \\
\text { Volatile compounds of non-vegetable origin } \\
\text { 15.955, 67, 81, 95,1091,4-Dichlorobenzene } \\
\text { 29.355, 69, 83, 91, 1051-Chlorodecane }\end{array}$}} & $\begin{array}{l}\text { MUSTY } \\
\text { ROTTEN }\end{array}$ & $\begin{array}{l}U \\
U \\
U \\
U\end{array}$ & $\begin{array}{l}U \\
U \\
U\end{array}$ & $U$ & $\begin{array}{l}U \\
U\end{array}$ & U & $U$ \\
\hline & & $\begin{array}{l}\text { Fresh } \\
\text { Musty }\end{array}$ & 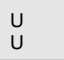 & 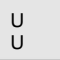 & U & $U$ & $\begin{array}{l}U \\
U\end{array}$ & $U$ \\
\hline
\end{tabular}

a-MA: active-MA, p-MA: passive-MA.

The major $\mathrm{m} / \mathrm{z}$ fragments are indicated in bold for each compound. Aromas and odors indicated in brackets were provided by the Flavornet database.

$a *\left(r_{2}>0.90\right)$ (results not shown). A good correlation between hue angle and $a^{*}$ values with visual scores was previously reported for passive MA-packaged Iceberg lettuce (Heimdal, Kuhn, Poll, \& Larsen, 1995). $\mathrm{DH} \star$ and $\mathrm{DE} \star$ were also markers of color and quality changes, respectively, for Iceberg lettuce and cabbage. Castaner, Gil, Artes, and Tomas-Barberan (1996) previously found that $\mathrm{a}^{\star}$ was the most suitable parameter to measure browning of Iceberg lettuce stem discs. For active MA-packaged Butterhead lettuce, the color and quality attributes were correlated with $\mathrm{DE} \star$ and DC*. For active MAP, the firmness measured using the Instron proved to be a suitable marker of the textural loss reported by sensory analysis $\left(r_{2}>0.90\right)$

\subsection{Volatile compounds}

Sixty-nine volatile organic emissions $(53$ for lettuce and 41 for cabbage) were detected and successfully identified (Table 1). Four of the compounds obtained were previously reported as lettuce volatile emissions: hexanol and benzaldehyde (Batten, Stutte, \& Wheeler, 1995), ethanol (Smyth et al., 1998) and nonanal (Batten et al., 1995; Stutte \& Wheeler, 1997). Three compounds were also previously identified as cabbage volatile emissions: hexanol and ethanol (Johnson et al., 1971) and limonene (Vuorinen et al., 2004).

Five phenols and a quinone (benzoquinone) were identified (Table 1). These volatile compounds are substrates of polypheno oxidase (PPO), an enzyme responsible for browning, as reported by Bassil, Makris, and Kefalas (2005). Thirteen terpenes, known as important characteristic aroma compounds in vegetables (Fischer \& Scott, 1997), were detected. Two volatile chlorinated compounds were identified: 1,4-dichlorobenzene (in both lettuce and cabbage) and 1-chlorododecane (only in lettuce). These emissions could have been produced as a result of the chlorine treatment, reinforcing the idea that potentially harmful chlorinated compounds can be formed during minimal processing, as reported by Sapers (2001). However, the chlorinated compounds may also have been derived from the preharvest application of the fungicide Rovral, whose active ingredient is the chlorinated compound iprodione. Orme and Kegley (2006) reported that 3,5-dichloroaniline was a possible breakdown product of iprodione. 1,4-Dichlorobenzene, identified in this study, and 3,5-dichloroaniline (1-amino-3,5-dichlorobenzene) have very similar structures, suggesting that 1,4-dichlorobenzene was a possible volatile breakdown product of Rovral.

Forty-five volatile compounds were perceived as aroma or odors using gas chromatography-olfactometry (Table 1). Four main categories of odors were distinguished: fresh, green, musty and rotten. A more precise description of each odor was provided by the Flavornet database. Four green smelling-compounds (limonene, (+)-cyclosativene, copaene and caryophyllene) were terpenes, confirming the contribution of the mevalonic pathway in the green aroma of lettuce and cabbage, as previously reported by Fischer and Scott (1997). Three phenolic compounds (4-ethylbenzaldehyde, 2,5-dimethylbenzaldehyde and trans-cinnamaldehyde) were perceived as fresh aromas, while two others (benzoquinone and ester benzoic acid) contributed to the musty odor. These results confirmed that enzymatic browning was accompanied with the release of odors via the action of the polyphenol oxidase (PPO) on phenols and quinines, as previously found by Nogueira, Lubachevsky, and Rankin (2005).

2-Phenoxyethanol was perceived as musty/rotten in all three vegetables. This compound possibly derived from ethanol, a product of fermentation reported by Lopez-Galvez et al. (1997) to be responsible for off-odors in Iceberg lettuce (3). 1-Chlorododecane was perceived as a musty off-odor in this study, while 1,4-dichlorobenzene was perceived as fresh. Hurst and Schuler (1992) previously showed that excessive free chlorine concentrations (>200 mg/l) caused the appearance of off-flavors (38). Delaquis, Stewart, Cliff, Toivonen, and Moyls (2000) reported that minimally processed Iceberg lettuce developed atypical aroma, but concluded that it was unclear whether such off-odors were derived from chlorine induced physiological changes or formation of volatile chlorinated compounds (39).

\subsection{Sensory quality markers}

Fifty-one volatile compounds were correlated $\left(r_{2}>0.90\right)$ with one or several sensory quality changes (Table 2). Among these 51 compounds, 29 were considered as quality markers as they correlated with the same sensory attributes in a minimum of two experiments. Six quality markers were common to the lettuce and cabbage species: 1,4-dichlorobenzene, limonene, 2-ethyl-1-hexanol, 2,4-bis-1,1-dimethylethylphenol, isobutyl ester pentanoic acid and thio-amino-butanamide. 1,4-Dichlorobenzene, perceived as fresh, was a marker of odor changes, loss of green color and browning $\left(r_{2}>0.90\right)$. Similarly, Hurst and Schuler (1992) reported adverse discolorations caused by excessive free chlorine concentrations (>200 mg/l) in lettuce. The terpene limonene was a marker of the loss of green color $\left(r_{2}>0.90\right)$, imparted by the green pigment chlorophyll, a polyterpenoid compound. The oxidation of terpenoid pigments produces a large range of volatile terpenes, so limonene is a possible oxidation product of chlorophyll in leafy green vegetables. Eleven quality-related compounds were common to Butterhead and Iceberg lettuces, among which six were specific to lettuce 
Table 2

Quality markers of MA-packaged Butterhead lettuce, Iceberg lettuce and Irish York cabbage detected over storage.

\begin{tabular}{|c|c|c|c|c|c|c|}
\hline \multirow{2}{*}{$\begin{array}{l}\text { Time } \\
(\mathrm{min})\end{array}$} & \multirow[t]{2}{*}{ Volatile compound } & \multicolumn{2}{|l|}{ MA Butterhead } & \multicolumn{2}{|l|}{ MA Iceberg } & \multirow{2}{*}{$\begin{array}{l}\text { MA Irish York cabbage } \\
\text { Active MA }\end{array}$} \\
\hline & & Active MA & Passive MA & Active MA & Passive MA & \\
\hline \multicolumn{7}{|c|}{ Volatile compounds of vegetable origin } \\
\hline \multicolumn{6}{|c|}{ 10.6P-xylene } & \multirow{18}{*}{$\begin{array}{l}\text { Off-odors, green color, yellowing, } \\
\text { texture } \\
\text { Odors, off-colors, texture, overall } \\
\text { quality } \\
\text { Green \& off-odors, green color, } \\
\text { browning, quality } \\
\text { Green \& off-odors, green color, } \\
\text { browning, quality } \\
\text { Aromas, off-odor, colors, quality }\end{array}$} \\
\hline 13.1 & 3-Carene & & & & & \\
\hline 16.4 & Cymene & & & & & \\
\hline 16.5 & Limonene & & & & & \\
\hline 16.6 & 2-Ethyl-1-hexanol & $\begin{array}{l}\text { Odors, browning, } \\
\text { firmness, quality }\end{array}$ & Odors, firmness & $\begin{array}{l}\text { Aromas, colors, } \\
\text { firmness, quality }\end{array}$ & Aromas, browning & \\
\hline 18.6 & Cis-3-dodecene & $\begin{array}{l}\text { Odors, off-colors, } \\
\text { texture, quality } \\
\text { Aromas, greenness, }\end{array}$ & & & & \\
\hline 21.0 & 4-Ethylbenzaldehyde & $\begin{array}{l}\text { yellowing, quality } \\
\text { Green odor, yellowing } \\
\text { Odors, off-colors, }\end{array}$ & & & & \\
\hline 21.4 & 3,5-Dimethylbenzaldehyde & texture, quality & & & & \\
\hline 21.5 & Trans-cinnamaldehyde & $\begin{array}{l}\text { Greenness } \\
\text { Green odor, greenness, } \\
\text { yellowing }\end{array}$ & & & & \\
\hline 21.6 & Decene & Off-odor & & & & \\
\hline 24.4 & Acetocinnamone & $\begin{array}{l}\text { Aromas, colors, firmness, } \\
\text { quality } \\
\text { Odors, colors, quality }\end{array}$ & & & & \\
\hline 25.0 & 2-Methylcoumaran & & & & & \\
\hline 26.1 & $\begin{array}{l}\text { 1,3-Diisocyanato-2- } \\
\text { methylbenzene } \\
\text { a-Longipinene }\end{array}$ & & & & & \\
\hline \multicolumn{2}{|l|}{26.2} & & Fresh \& off-odor, colors & $\begin{array}{l}\text { Rotten odor, } \\
\text { firmness }\end{array}$ & Green odor & \\
\hline 26.3 & $\begin{array}{l}\text { 2,4-Diisocyanato-1- } \\
\text { methylbenzene }\end{array}$ & $\begin{array}{l}\text { Aromas, colors, firmness, } \\
\text { quality }\end{array}$ & Fresh \& off-odors & & & \\
\hline \multicolumn{2}{|r|}{ Copaene } & & Firmness, odors & $\begin{array}{l}\text { Fresh \& musty } \\
\text { odor, firmness }\end{array}$ & $\begin{array}{l}\text { Fresh \& musty odor, } \\
\text { firmness }\end{array}$ & \\
\hline 27.2 & b-Elemene & $\begin{array}{l}\text { Odors, colors, texture, } \\
\text { quality }\end{array}$ & Odors & & & \\
\hline $\begin{array}{l}28.1 \\
30.0\end{array}$ & $\begin{array}{l}\text { Caryophyllene } \\
\text { Butylated hydroxytoluene }\end{array}$ & $\begin{array}{l}\text { Lettuce \& musty odors, } \\
\text { rotten odor, colors, } \\
\text { texture, quality } \\
\text { Odors, colors, firmness, } \\
\text { quality }\end{array}$ & $\begin{array}{l}\text { Colors, texture, quality, } \\
\text { aromas }\end{array}$ & & & \\
\hline 30.2 & $\begin{array}{l}\text { 2,4-Bis (1,1-dimethylethyl)- } \\
\text { phenol }\end{array}$ & & Colors, quality & $\begin{array}{l}\text { Green, fresh \& } \\
\text { musty odor, } \\
\text { browning, quality }\end{array}$ & & $\begin{array}{l}\text { Green \& off-odor, Musty \& rotten } \\
\text { odors, green color, browning, } \\
\text { texture, quality }\end{array}$ \\
\hline 32.1 & $\begin{array}{l}\text { 2,2,4-Trimethyl-3- } \\
\text { carboxyisopropyl isobutyl } \\
\text { ester pentanoic acid } \\
\text { Diphenyl sulfide }\end{array}$ & Odors, colors, quality & Odors & $\begin{array}{l}\text { Green, fresh \& } \\
\text { musty odor, } \\
\text { browning, quality }\end{array}$ & & Odors, colors, quality \\
\hline \multicolumn{2}{|r|}{ 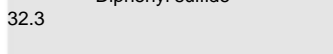 } & Firmness & $\begin{array}{l}\text { Aromas, colors, } \\
\text { firmness, quality }\end{array}$ & & & \\
\hline 33.4 & $\begin{array}{l}\text { N-Methyl-4-(methylthio-Aron } \\
\text { dimethylpropylidene)yellowir } \\
\text { amino-butanamidequality }\end{array}$ & $\begin{array}{l}\text { nness, } \\
\text {, }\end{array}$ & $\begin{array}{l}\text { Green \& lettuce odor, } \\
\text { firmness, quality, fresh } \\
\text { \& off-odors }\end{array}$ & $\begin{array}{l}\text { Rotten odor, } \\
\text { firmness }\end{array}$ & $\begin{array}{l}\text { Lettuce, musty \& } \\
\text { rotten odor, } \\
\text { yellowing, firmness }\end{array}$ & Texture \\
\hline $\begin{array}{l}\text { Volatile } \\
15.91,\end{array}$ & $\begin{array}{l}\text { bis-phenol } \\
\text { :ompounds of non-vegetable } \\
\text { DichlorobenzeneOdors, off-co }\end{array}$ & olors, quality44.14,4-(1-Met & lidene)- & & & \\
\hline \multicolumn{4}{|c|}{ 29.31-ChlorododecaneOff-odors, browning } & $\begin{array}{l}\text { Rotten odor, } \\
\text { yellowing }\end{array}$ & $\begin{array}{l}\text { Aromas, greenness, } \\
\text { browning }\end{array}$ & $\begin{array}{l}\text { Green \& off-odors, green color, } \\
\text { browning, quality }\end{array}$ \\
\hline
\end{tabular}

MA: modified atmosphere

Sensory attributes indicated in bold were correlated with volatile compounds in a minimum of two experiments $\left(r_{2}>0.90\right)$.

(Table 2). Four of them were sesquiterpenes (a-longipinene, $(+)$ cyclosativene, copaene, caryophyllene), produced by the mevalonic pathway. (+)-cyclosativene, copaene and caryophyllene, perceived as green aromas of leafy green vegetables, were correlated with fresh aroma $\left(r_{2}>0.90\right)$. a-Longipinene, associated with a rotten odor, was a marker of the loss of green odor and the development of rotten off-odor $\left(r_{2}>0.90\right)$.

Nine volatile compounds were found very highly correlated $2(r>0.90)$ with quality attributes for active MA-packaged Butterhead lettuce (Tables 2 and 3): 2-ethyl-1-hexanol, cis-3-dodecene, 4-ethylbenzaldehyde, acetocinnamone, b-elemene, 1-chlorododecane, dimethylethylphenol, ester pentanoic acid and thio-aminobutanamide. 2-Ethyl-1-hexanol, previously identified in lettuce
(Batten et al., 1995), increased over storage from $2 \%$ to $7 \%$ of the total volatile emissions (Fig. 2). The increase in this musty-smelling compound was correlated with odor changes, browning and loss of quality in active MA-packaged Butterhead lettuce $\left(r_{2}>0.90\right)$ (Table 2). This quality loss factor possibly derived from hexan-1ol, a product of the lipoxygenase pathway (Charron \& Cantliffe, 1995) responsible for the biosynthesis of green leaf volatiles (Arey et al., 1991). The absence of the green leaf volatiles, main products of the LOX pathway and responsible for fresh and green aromas in leafy green vegetables (Arey et al., 1991), could be due to an alteration of the LOX pathway by cutting. Charron and Cantliffe (1995) previously identified an enhancement of LOX activity in lettuce as a result of mechanical injury. 
Major volatile quality markers of active MA-packaged Butterhead lettuce.

\begin{tabular}{|c|c|c|c|c|}
\hline \multirow[t]{2}{*}{ Volatile biomarker } & \multicolumn{3}{|c|}{ Concentration $(\%) \pm$ standard deviation } & \multirow[t]{2}{*}{ Correlation $\left(r_{2}>0.90\right)$} \\
\hline & Day 1 & Day 7 & Day 14 & \\
\hline \multirow[t]{2}{*}{$\begin{array}{l}\text { Volatile compounds of vegetable origin } \\
\text { 2-Ethyl-1-hexanol } \\
\text { Cis-3-dodecene } \\
\text { 4-Ethylbenzaldehyde } \\
\text { Acetocinnamone } \\
\text { b-Elemene } \\
\text { 2,4-Bis (1,1-dimethylethyl)-phenol } \\
\text { 2,2,4-Trimethyl-3-carboxyisopropyl isobutyl ester pentanoic acid } \\
\text { N-Methyl-4-methylthiodimethylpropylidene-aminobutanamide } \\
\text { Volatile compound of non-vegetable origin } \\
\text { 1-Chlorododecane }\end{array}$} & $\begin{array}{l}2.19 \pm 1.53 \\
0.00 \pm 0.00 \\
0.47 \pm 0.29 \\
0.57 \pm 0.19 \\
0.98 \pm 0.44 \\
3.60 \pm 2.33 \\
4.88 \pm 6.26 \\
4.25 \pm 1.93\end{array}$ & $\begin{array}{r}4.06 \pm 3.99 \\
4.28 \pm 3.35 \\
1.11 \pm 0.53 \\
0.66 \pm 0.23 \\
1.50 \pm 0.57 \\
2.49 \pm 0.83 \\
4.38 \pm 5.33 \\
16.13 \pm 9.92\end{array}$ & $\begin{array}{r}6.90 \pm 3.26 \\
28.35 \pm 8.76 \\
1.89 \pm 0.88 \\
0.55 \pm 0.21 \\
2.54 \pm 1.20 \\
1.06 \pm 0.65 \\
2.08 \pm 2.21 \\
2.31 \pm 5.28\end{array}$ & $\begin{array}{l}\text { Odors, browning, quality } \\
\text { Odors, off-color, texture } \\
\text { Aromas, yellowing, quality } \\
\text { Green odor, green color, yellowing } \\
\text { Odors, colors, texture, quality } \\
\text { Off-odors, browning } \\
\text { Odors, colors, texture, quality } \\
\text { aromas, green color, texture, yellowing }\end{array}$ \\
\hline & $0.50 \pm 0.23$ & $0.62 \pm 0.25$ & $0.32 \pm 0.42$ & Off-odors, browning \\
\hline
\end{tabular}

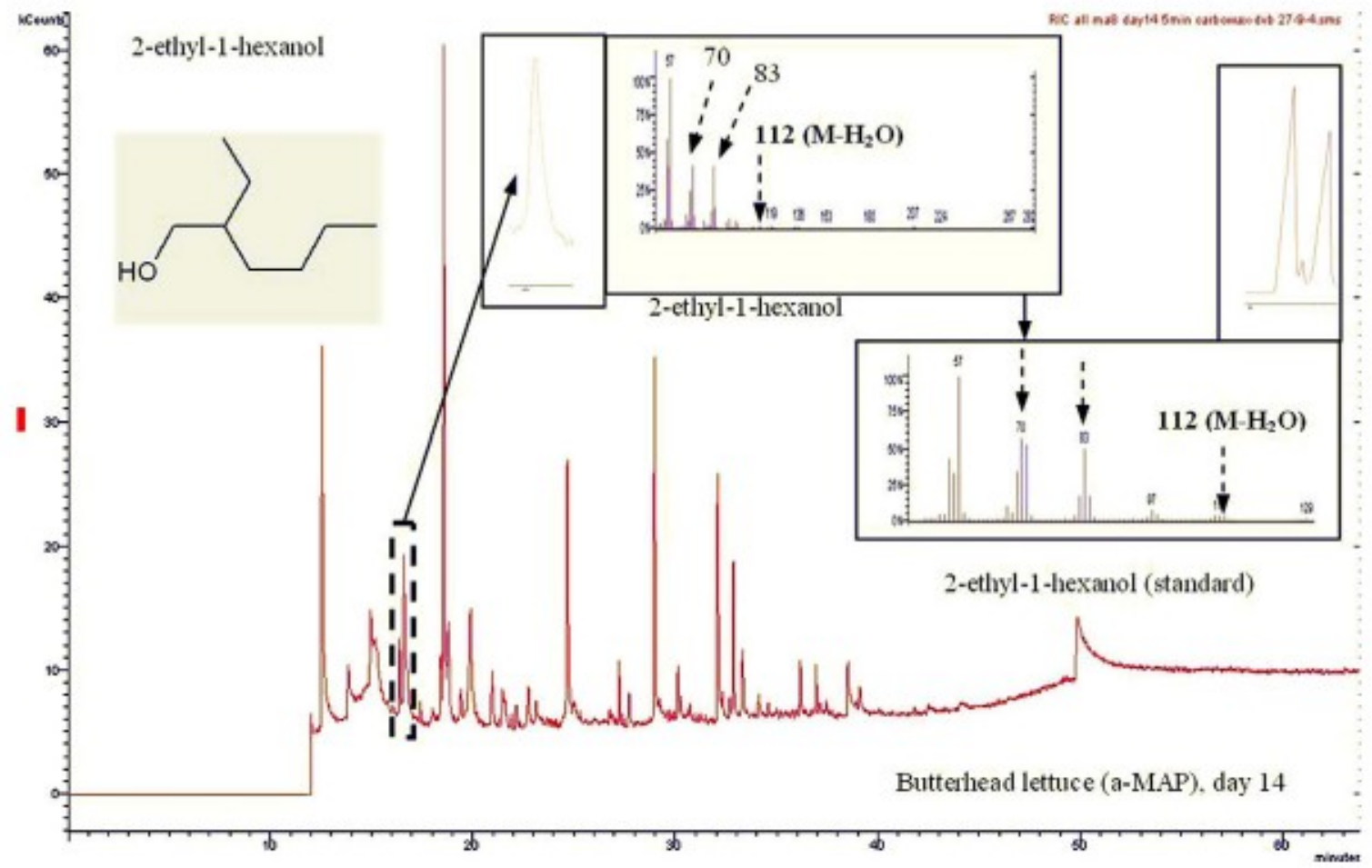

Fig. 2. Structure and identification of 2-ethyl-1-hexanol in active MA-packaged Butterhead lettuce (day 14) (Lonchamp, Barry-Ryan and Devereux).

Cis-3-dodecene was not detected in any product at day 1 . This peak only appeared between days 1 and 7 . A dramatic increase of this compound then occurred between days 7 and 14, reaching $28 \%$ of total emissions in active MA-packaged Butterhead lettuce on day 14 . The dramatic increase of this rotten-smelling compound was a marker of quality loss (odor and texture changes) and offcolor development $\left(r_{2}>0.90\right)$

The concentration of 4-ethylbenzaldehyde, previously detected in lettuce (Batten et al. 1995), increased from $0.5 \%$ of total emissions at day 1 to $2 \%$ at day 14 . This increase was correlated $\left(r_{2}>0.90\right)$ with the aroma loss, yellowing and quality loss. Although no odor was perceived, a sweet aroma is usually associated with 4-ethylbenzaldehyde according to the Flavornet database. 4-Ethylbenzaldehyde was emitted by the phenylpropanoid acid pathway, responsible for enzymatic browning as reported by Bassil et al. (2005)

Acetocinnamone remained stable, around $0.6 \%$ of total volatiles (Table 3). This compound was correlated with green odor, green color and yellowing in active MA-packaged Butterhead lettuce $\left(r_{2}>0.90\right)$. Ionone compounds, such as acetocinnamone, result from the mevalonic acid metabolism, also producing monoterpenes and sesquiterpenes which contribute to fresh lettuce aroma (Fischer \& Scott, 1997). The correlation between acetocinnamone and green odor loss may be due to the decrease of green-smelling terpenes over storage. Acetocinnamone is also a product of the oxidation of the yellow tetraterpenoid carotenoid pigments (Enzell \& Wahlberg, 1980), explaining the correlation between acetocinnamone and yellowing. Acetocinnamone was also correlated with the loss of green color $\left(r_{2}>0.90\right)$, due to the degradation of the green pigment chlorophyll by the enzyme chlorophyllase (Bolin \& Huxsoll, 1991). This result suggested that the terpenoid acetocinnamone could be a product of the degradation of the polyterpenoid chlorophyll.

b-Elemene increased over storage from $1 \%$ to $3 \%$ of total emis sions (Fig. 3), and was correlated with changes of all the sensory parameters monitored $\left(r_{2}>0.90\right)$. This musty-smelling compound was one of the terpenes emitted by the mevalonic pathway. The formation of off-odors by the mevalonic pathway could be due to a wound-induced alteration of this metabolism caused by cutting. Mechanical injury was previously showed to influence metabolic 


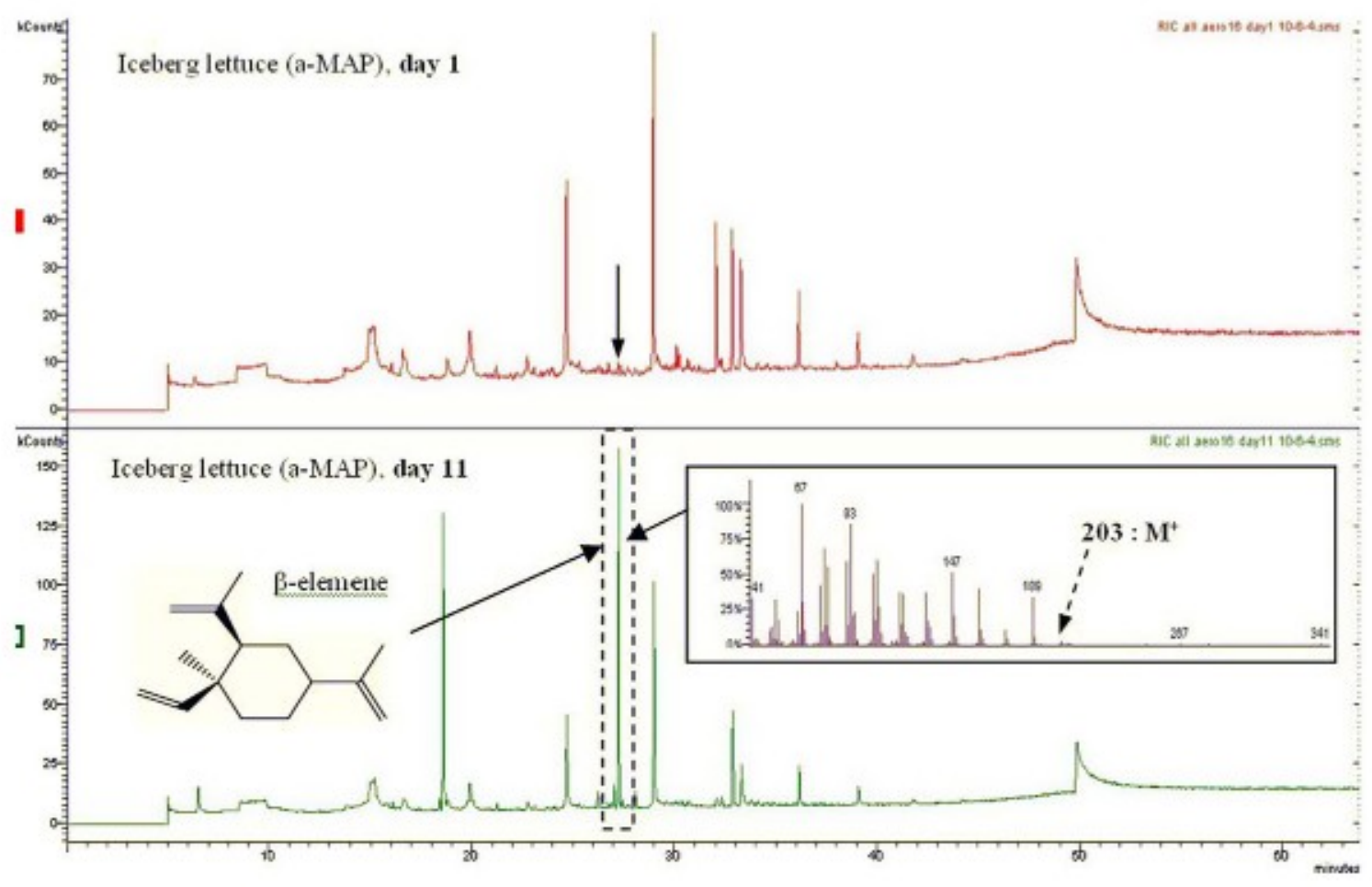

Fig. 3. Increase of b-elemene between days 1 and 11 in active MA-packaged Iceberg lettuce (Lonchamp, Barry-Ryan and Devereux).

pathways, including the lipoxygenase pathway (Charron \& Cantliffe, 1995) and the phenylpropanoid acid pathway (Choi et al., 2005). 1-Chlorododecane was low and slightly decreased during the storage (around $0.5 \%$ of total volatiles). Development of offodors and browning were statistically related to this musty-smelling emission $\left(r_{2}>0.90\right)$. 1-Chlorododecane either derived from the chlorinated fungicide Rovral used by the grower or from the chlorine treatment used during minimal processing.

2,4-Bis-1,1-dimethylethylphenol decreased from 4\% at day 1 to $1 \%$ at day 14 . This phenolic compound was emitted by the browning-related phenylpropanoid acid pathway. The decrease of this green-smelling compound was highly correlated with development of off-odors and browning $\left(r_{2}>0.90\right)$. This correlation is in accordance with results from Nogueira et al. (2005), who found that enzymatic browning was accompanied by the release of off-odors in lettuce. This volatile emission was possibly released during the conversion of phenols to polyphenols by the phenylpropanoid acid pathway. Isobutyl ester pentanoic acid decreased slightly from day $1(5 \%)$ to day 7 , then dropped to $2 \%$ between days 7 and 14 . This fresh-smelling emission was highly correlated with changes of all the sensory parameters monitored $\left(r_{2}>0.90\right)$. Isobutyl ester pentanoic acid possibly derived from mevalonic acid (pentanoic acid), substrate of the mevalonic acid pathway producing green-smelling terpenes.

Thio-amino-butanamide dramatically increased from $4 \%$ of total emissions at day 1 to $16 \%$ at day 7 . Then its level dramatically dropped between days 7 and 14 , reaching $6.5 \%$. This musty-smelling compound was statistically $\left(r_{2}>0.90\right)$ linked to quality loss (aromas, green color, texture) and yellowing. Thio-amino-butanamide had a similar structure to a part of the amino group of iprodione, the active ingredient of the fungicide Rovral used on Butterhead lettuce. This analyte could be, as suggested for 1,4-dichlorobenzene, a breakdown product of iprodione in Butterhead lettuce.

The two sesquiterpenes 3-carene and p-xylene were specific biomarkers of Irish York cabbage. P-xylene was associated with a green aroma, and its decrease over storage was correlated $\left(r_{2}>0.90\right)$ with textural changes. 3-Carene, produced by the mevalonic pathway, was perceived as fresh and its decrease was correlated $\left(r_{2}>0.90\right)$ with browning and yellowing.

A dramatic increase in four compounds occurred in several active MA-packaged cabbage bags at the beginning of storage but did not last until day 7 . These emissions were 1,3-diisocyanato-2-methylbenzene,2,4-diisocyanato-1-methylbenzene, 2,3-dihydro-6-amino-indole-2-one and 1,3-dihydro-3-methyl$2 \mathrm{H}$-benzimidazol-2-one. The first three analytes were perceived as musty. Volatile cyanate derivatives have been shown to be tied up to non-volatile glycosides (glucosinolates) in cabbage (Rosa, Heaney, Fenwick, \& Portas, 1997). Their short-term increase at the beginning of the storage may be explained by their release from their glycoside precursors via the action of the myrosinase (Fahey, Zalcmann, \& Talalay, 2001), in contact with its substrates as a result of the cellular delocalisation occurring during cutting. The emission of these compounds was a possible marker of the stress-induced onset of major physiological changes as a result of minimal processing.

\section{Conclusions}

The aim of this study was to assess possible correlations between changes in the sensory and volatile emission profiles of three leafy green vegetables (Butterhead lettuce, Iceberg lettuce and Irish York cabbage). Two types of samples were monitored: a high quality product (active MAP) and a low quality standard (passive MAP). Twenty-nine volatile organic compounds were correlated as quality markers in the leafy green vegetables studied $\left(r_{2}>0.90\right)$. Nine main quality markers were identified for active MA-packaged Butterhead lettuce: 2-ethyl-1-hexanol, cis-3-dodecene, 4-ethylbenzaldehyde, acetocinnamone, b-elemene, 1-chlorododecane, dimethylethylphenol, ester pentanoic acid and thio-amino-butanamide. The main markers of freshness for Butterhead lettuce were 
dimethylethylphenol and ester pentanoic acid, while the main quality loss markers were cis-3-dodecene and b-elemene.

Possible outcomes of this work could be the development of novel quality-monitoring methods based on volatile emission changes, such as on-line units monitoring the volatile profile at the industrial level and active food labels that would respond to a biomarker changes at the consumer level. These quality-monitoring methods can also be applied for the optimisation of the processing and packaging of ready-to-use vegetables in shelf-life trials, with a view to extending their shelf-life. Further work could be carried out to optimise the biomarker detection method developed in this work, especially on the extraction step using SPME. Further studies could investigate the microbiological profiles of these produce in order to determine the possible microbial origin of certain volatile markers.

\section{Acknowledgments}

The authors wish to thank Elaine Clarke and Helen Farrell for their technical assistance.

\section{References}

Arey, J., Winer, A. M., Atkinson, R., Aschmann, S. M., Long, W. D., \& Morrison, C. L. (1991). The emission of (Z)-3-hexen-1-ol, (Z)-3-hexenylacetate and other oxygenated hydrocarbons from agricultural plant species. Atmospheric Environment, 5/6, 1063-1076

Ballantyne, A., Stark, R., \& Selman, J. D. (1998). Modified atmosphere packaging of shredded lettuce. International Journal of Food Science and Technology, 23, 267-274.

Bassil, D., Makris, D. P., \& Kefalas, P. (2005). Oxidation of caffeic acid in the presence of L-cysteine: Isolation of 2-S-cysteinylcaffeic acid and evaluation of its antioxidant properties. Postharvest Biology and Technology, 38, 395-402.

Batten, J. H., Stutte, G. W., \& Wheeler, R. M. (1995). Effect of crop development on biogenic emissions from plant populations grown in closed plant growth chambers. Phytochemistry, 39(6), 1351-1357.

Belitz, H. D., \& Grosch, W. (1987). In H. D. Belitz \& W. Grosch (Eds.), Food chemistry (3rd ed.). Berlin: Spinger-Verlag.

Bianco, V. V. (1990). Lattuga. In V. V. Bianco \& F. Pimpini (Eds.), Orticoltura (pp. 270-308). Bologna: Patron editore.

Bolin, H. R., \& Huxsoll, C. C. (1991). Control of minimally processed carrot (Daucus carota) surface discoloration caused by abrasion peeling. Journal of Food Science, $56,416-418$

Carlin, F., Nguyen-The, C., Hilbert, G., \& Chambroy, Y. (1990). Modified atmosphere packaging of fresh, "ready-to-use" grated carrots in polymeric films. Journal of Food Science, 55(4), 1033-1037.

Castaner, M., Gil, M. I., Artes, F., \& Tomas-Barberan, F. A. (1996). Inhibition of browning of harvested head lettuce. Journal of Food Science, 61(2), 314-316.

Charron, C. S. \& Cantliffe, D. J. (1995). Volatile emissions from plants. Horticultura Reviews, 17, 43-72.

Charron, C. S., Cantliffe, D. J., Wheeler, R. M., Manukian, A., \& Heath, R. R. (1996a). A system and methodology for measuring volatile organic compounds produced by hydroponic lettuce in a controlled environment. Journal of the American Society of Horticultural Science, 121(3), 483-487.

Charron, C. S., Cantliffe, D. J., Wheeler, R. M., Manukian, A., \& Heath, R. R. (1996b) Photosynthetic photon flux, photoperiod, and temperature effects on emissions of (Z)-3-hexenal, (Z)-3-hexenol, and (Z)-3-hexenyl acetate from lettuce. Journal of (Z)-3-hexenal, (Z)-3-hexenol, and (Z)-3-hexenyl acetate from lett
of the American Society of Horticultural Science, 121(3), 488-494.

Chin, H. W., \& Lindsay, R. C. (1993). Volatile sulfur compounds formed in disrupted tissues of different cabbage cultivars. Journal of Food Science, 58, 835-839.
ting

Choi, Y. C., Tomas-Barberan, F. A., \& Salveit, M. E. (2005). Wound-induced phenolic accumulation and browning in lettuce (Lactuca sativa L.) leaf tissue is reduced accumulation and browning in lettuce (Lactuca sativa L.) leaf tissue is reduced
by exposure to $n$-alcohols. Postharvest Biology and Technology, 37, 47-55.

Delaquis, P. J., Stewart, S., Cliff, M., Toivonen, P. M., \& Moyls, A. L. (2000). Sensory quality of ready-to-eat lettuce washed in warm, chlorinated . Ler. Journal of Food Quality, 23, 553-563.
Enzell, C. R., \& Wahlberg, I. (1980). Leaf composition in relation to smoking quality and aroma. Recent Advances in Tobacco Science, 6, 64-122.

Fahey, J. W., Zalcmann, A. T., \& Talalay, P. (2001). The chemical diversity and distribution of glucosinolates and isothiocyanates among plants. Journal of Phytochemistry, 26, 5-51.

Fischer, C., \& Scott, T. R. (1997). Flavor compounds. In C. Fischer \& T. R. Scott (Eds.), Food flavors: Biology and chemistry (pp. 15-75). Letchworth, UK: RSC Paperbacks.

Flavornet database. <www.flavornet.org>.
Gil, M. I., Castaner, M., Ferreres, F., Artes, F., \& Tomas-Barberan, F. A. (1998), Modified-atmosphere packaging of minimally processed "Lollo Rosso" (Lactuca sativa) - Phenolic metabolites and quality changes. Zeitschrift für sativa) - Phenolic metabolites and quality changes. Zeitschr
Lebensmitteluntersuchung und Forschung A, 206, 350-354.

Hamza, F., Castaigne, F., Willemot, C., Doyon, G., \& Makhouf, J. (1996). Storage of minimally processed romaine lettuce under controlled atmosphere. Journal of Food Quality, 19, 177-188.

Heimdal, H., Kuhn, B. F., Poll, L., \& Larsen, L. M. (1995). Biochemical changes and sensory quality of shredded and MA-packaged iceberg lettuce. Journal of Food Science, 60(6), 1265-1268.

Hurst, W. C., \& Schuler, G. A. (1992). Fresh produce processing - An industry perspective. Journal of Food Protection, 55, 824-827.

Johnson, A. E., Nursten, H. E., \& Williams, A. A. (1971). Vegetables volatiles: A survey of components identified - Part II. Chemistry and Industry, 1212-1224.

Lalel, H. J. D., Singh, Z., \& Tan, S. C. (2003). Glycosidically-bound aroma volatile compounds in the skin and pulp of "Kensington Pride" mango fruit at differen stages of maturity. Postharvest Biology and Technology, 29, 205-218.

Li, Y., Brackett, R. E., Shewfelt, R. L., \& Beuchat, L. R. (1991). Changes in appearance and natural microflora on iceberg lettuce treated in warm, chlorinated water and then stored at refrigeration temperature. Food Microbiology, 18, 299-308.

Lopez-Galvez, G., Peiser, G., Nie, G. X., \& Cantwell, M. (1997). Quality changes in packaged salad products during storage. Zeitschrift für Lebensmitteluntersuchung und Forschung A, 205, 64-72.

Martinez, J. A., \& Artes, F. (1999). Effect of packaging treatments and vacuumcooling on quality of winter harvested Iceberg lettuce. Food Research International, 32, 621-627.

Mc Kellar, R. C., Odumeru, J., Zhou, T., Harrison, A., Mercer, D. G., Young, J. C., et al. (2004). Influence of a commercial warm chlorinated water treatment and packaging on the shelf-life of ready-to-use lettuce. Food Research International, 37, 343-354.

Nogueira, M. C. L., Lubachevsky, G., \& Rankin, S. A. (2005). A study of the volatile composition of Minas cheese. Lebensmittel-Wissenschaft und Technologie, 38, 555-563.

Orme, S., \& Kegley, S. (2006). PAN Pesticide Database. Pesticide Action Network. $<$ http:www. pesticideinfo.org>

Rosa, E. A. S., Heaney, R. K., Fenwick, G. R., \& Portas, C. A. M. (1997). Glucosinolates in crop plants. Horticultural Reviews, 19, 99-215.

Rosenfeld, H. J., \& Sundell, H. A. (1992). Color, taste, texture and shelf-life of crisphead lettuce in PP-bags. In Modified atmosphere packaging (conference) (pp. 157-164). Commission of the European Communities.

Sapers, G. M. (2001). Efficacy of washing and sanitizing methods for disinfection of fresh fruit and vegetable products. Food Technology and Biotechnology, 39(4), 305-311.

Sarry, J.-E., \& Gunata, Z. (2004). Plant and microbial glycoside hydrolase: Volatile release from glycosidic aroma precursors. Food Chemistry, 87(4), 509-521.

Smyth, A. B., Song, J., \& Cameron, A. C. (1998). Modified atmosphere packaged cut lettuce: Effect of temperature and $\mathrm{O}_{2}$ partial pressure on respiration and quality. Journal of Agricultural and Food Chemistry, 46, 4556-4562.

Stutte, G. W. \& Wheeler, R. M. (1997). Accumulation and effect of volatile organic compounds in closed life support systems. Advances in Space Research, 20(10), 1913-1922.

Toole, G. A., Parker, M. L., Smith, A. C., \& Waldron, K. W. (2000). Mechanical properties of lettuce. Journal of Material Science, 35, 3553-3559.

Vuorinen, T., Reddy, G. V. P., Nerg, A-M., \& Holopainen, J. K. (2004). Monoterpene and herbivore-induced emissions from cabbage plants grown at elevated atmospheric $\mathrm{CO}_{2}$ concentration. Atmospheric Environment, 38, 675-682.

Watada, A. E., \& Qui, L. (1999). Quality of fresh-cut produce. Postharvest Biology and Technology, 15, 201-205.

Yao, H., \& Tian, S. (2005). Effects of pre-and post-harvest application of salicylic acid or methyl jasmonate on inducing disease resistance of sweet cherry fruit in storage. Postharvest Biology and Technology, 35, 253-262

Zhou, T., Harrison, A. D., McKellar, R., Young, J. C., Odumeru, J., Piyasena, P., et al. (2004). Determination of acceptability and shelf-life of ready-to-use lettuce by digital image analysis. Food Research International, 37, 875-881. 